\title{
THE DIGESTIVE FLUID OF DROSERA INDICA CONTAINS A CYSTEINE ENDOPEPTIDASE (“DROSERAIN") SIMILAR TO DIONAIN FROM DIONAEA MUSCIPULA
}

\begin{abstract}
Kenji Takahashi - School of Life Sciences - Tokyo University of Pharmacy and Life Sciences • 1432-1 Horinouchi • Hachioji • Tokyo 192-0392 • Japan • and Department of Biology • School of Life Dentistry • The Nippon Dental University • Chiyoda-ku • Tokyo 102-8159 • Japan • kenjitak@toyaku.ac.jp

WatARU NishII • Systems and Structural Biology Center • RIKEN • Kanagawa 230-0045 • Japan

Chiaki Shibata • Department of Biology $\bullet$ School of Life Dentistry • The Nippon Dental University

- Chiyoda-ku・Tokyo 102-8159・ Japan
\end{abstract}

Keywords: chemistry, Drosera indica, cysteine endopeptidase, droserain, Dionaea muscipula, dionain, aspartic endopeptidase.

Received: 11 September 2012

\section{Introduction}

Carnivorous plants are known to secrete various endopeptidases extracellularly to digest prey proteins. Previously we purified two isoforms of nepenthesin to homogeneity and elucidated their enzymatic and structural characteristics (Athauda et al. 1998, 2002, 2004; Takahashi et al. 2003, 2005). In a continuation of these studies, we have been attempting to characterize these and other endopeptidases secreted by carnivorous plants to digest prey proteins (Takahashi et al. 2009). Recently, we found and partially characterized a cysteine endopeptidase in the digestive fluid of Dionaea muscipula and named it "dionain" (Takahashi et al. 2011). In the present report, we describe the occurrence of a similar cysteine endopeptidase in the digestive fluid of Drosera indica and propose the name "droserain" to this enzyme. In this connection, we also propose the names of aspartic endopeptidases from the digestive fluids of relevant carnivorous plants.

\section{Materials and Methods}

The crude digestive fluid of wild specimens of Drosera indica was obtained in the Watarase retarding basin area, Tochigi. The digestive fluid was collected by soaking thirty leaves successively (1 leaf for $1 \mathrm{~min}$ at a time) in $10 \mathrm{ml}$ of distilled water in a test tube to wash out the digestive fluid through up-and-down strokes. The diluted digestive fluid thus obtained was stored frozen until use. Benzyloxycarbonyl-Phe-Arg 4-methyl-7-coumarylamide (Z-Phe-Arg-MCA), a cysteine endopeptidase substrate, trans-epoxysuccinyl-L-leucylamido(4-guanidino)butane (E-64) and pepstatin A were obtained from Peptide Institute, Osaka. Other reagents used were of analytical grade.

To measure the activity toward Z-Phe-Arg-MCA, the reaction mixture contained $20 \mu \mathrm{L}$ of the diluted fluid, $5 \mu \mathrm{l}$ of $2 \mathrm{mM}$ Z-Phe-Arg-MCA in dimethyl sulfoxide, $75 \mu 1$ of $100 \mathrm{mM}$ buffer at various $\mathrm{pH}$ values, and $\pm 10 \mathrm{mM}$ dithiothreitol (DTT). The mixture was incubated at $37^{\circ} \mathrm{C}$ and the increase in fluorescence at $460 \mathrm{~nm}$ with excitation at $370 \mathrm{~nm}$ was measured at 5-min intervals for $60 \mathrm{~min}$, and the activity was determined from the slope of the digestion curve. To measure the effects of other agents, a small volume of each reagent solution (e.g., $1 \mu \mathrm{l}$ of $1 \mathrm{M}$ DTT and $1 \mu \mathrm{l}$ of $1 \mathrm{mM}$ E-64) was 
- Droserain

$\Delta$ Dionain

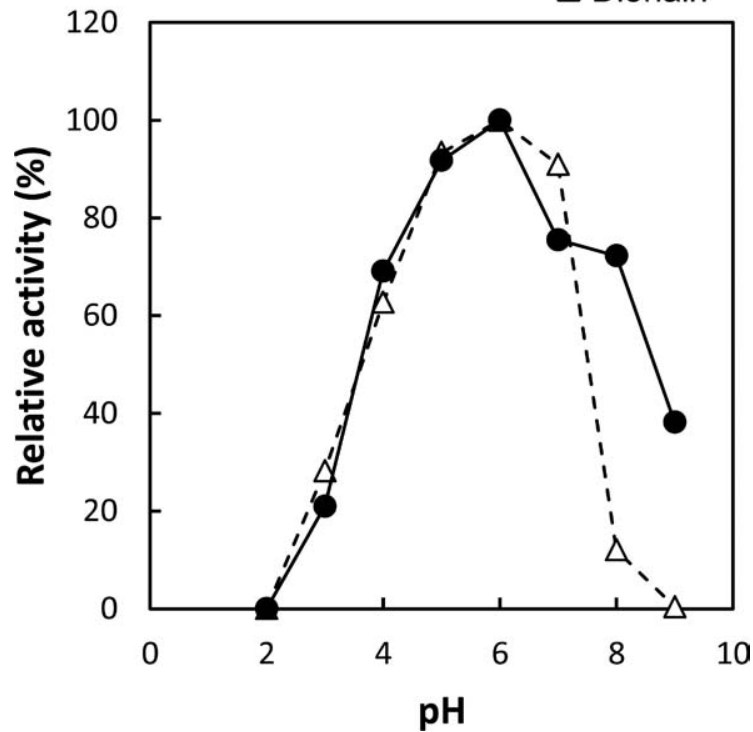

Figure 1: $\mathrm{pH}$ dependence of the activities toward Z-Phe-Arg-MCA of the digestive fluids of Drosera indica (droserain) and Dionaea muscipula (dionain) in the presence of $10 \mathrm{mM}$ DTT. The activity at $\mathrm{pH}$ 6.0 was taken as $100 \%$. The buffers ( $100 \mathrm{mM}$ ) used were $\mathrm{KCl}-\mathrm{HCl}, \mathrm{pH} 2.0$, sodium citrate, $\mathrm{pH}$ 3.0-6.0, potassium phosphate, $\mathrm{pH}$ 6.0-8.0, and Tris-HCL, pH 8.0 and 9.0.

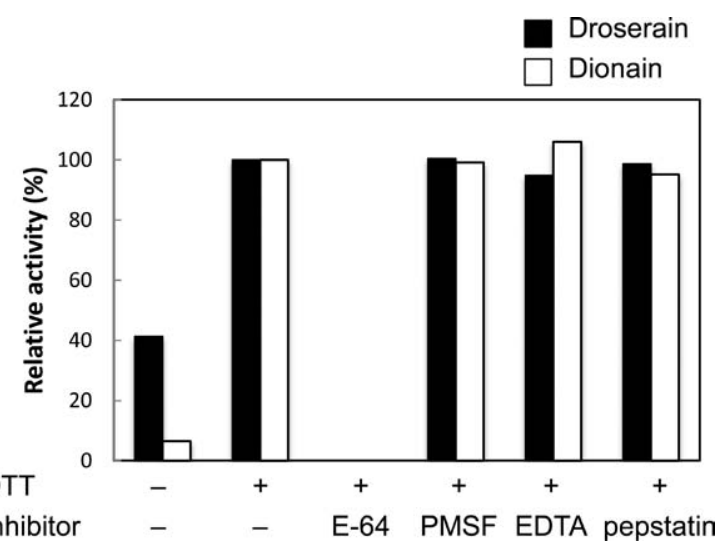

Figure 2: Effects of inhibitors on the activities toward Z-Phe-Arg-MCA of the digestive fluids of Drosera indica (droserain) and Dionaea muscipula (dionain) in the presence of $10 \mathrm{mM} \mathrm{DTT}$ at $\mathrm{pH}$ 6.0. The final concentrations of the inhibitors were E-64: $10 \mu \mathrm{M}$, PMSF: 1mM, EDTA: $5 \mathrm{mM}$, and pepstatin A: $1 \mu \mathrm{M}$. added, and the mixture was preincubated at $37^{\circ} \mathrm{C}$ for $5 \mathrm{~min}$ before addition of the substrate. For comparison, the activity of dionain in the digestive fluid of Dionaea muscipula was also measured under the same conditions using $2 \mu$ of the crude digestive fluid in a total volume of $100 \mu \mathrm{l}$ made up with distilled water.

\section{Results and Discussion}

Figure 1 shows the $\mathrm{pH}$ dependence of endopeptidase activity toward Z-Phe-Arg-MCA in the presence of $10 \mathrm{mM}$ DTT. The maximal activity was observed at $\mathrm{pH} 6.0$, and about $20 \%$ and $40 \%$ of the maximal activity was observed even at $\mathrm{pH} 3.0$ and 9.0, respectively. This indicates that the enzyme is capable of acting in a wide range of $\mathrm{pH}$ extending from acidic to weakly alkaline region. In the absence of DTT, about $40 \%$ of the activity in the presence of $10 \mathrm{mM}$ DTT was observed (Fig. 2). A similar $\mathrm{pH}$ dependence of activity was observed with dionain in the presence of $10 \mathrm{mM}$ DTT except that the present enzyme showed notable activity at $\mathrm{pH}$ 8-9 unlike dionain. The shoulder of activity at $\mathrm{pH}$ 8-9 may indicate the presence of the second cysteine endopeptidase.

Furthermore, the enzyme was completely inhibited by $10 \mu \mathrm{M}$ E-64 (a cysteine peptidase inhibitor) whereas it was not inhibited by phenylmethanesulfonyl fluoride (a serine peptidase inhibitor), EDTA (a metallopeptidase inhibitor), and pepstatin A (aspartic peptidase inhibitor) as shown in Figure 2. The inhibitory profiles of these inhibitors were essentially the same with dionain (Fig. 2). These results show the occurrence of a cysteine endo- 
peptidase similar to dionain in the digestive fluid of Drosera indica. We propose the name "droserain" for this enzyme. In this connection, we also propose the names of aspartic endopeptidases from the digestive fluids of Dionaea muscipula (Venus Flytrap), Drosera (sundew) sp., and Cephalotus follicularis as "dionaeasin", "droserasin", and "cephalotusin", respectively, as previously suggested (Takahashi 2003).

In the present study, $20 \mu \mathrm{l}$ of the diluted digestive fluid was used for the assay of droserain, whereas $2 \mu 1$ of the crude digestive fluid was used for the assay of dionain, and the activity observed for the latter was 4.2 times higher than that for the former. Therefore, one leaf of $D$. indica was calculated to contain approximately $8 \mu \mathrm{l}$ equivalent of the digestive fluid of D. muscipula. This value appears to be fairly reasonable. The present enzyme is thought to work in concert with the aspartic endopeptidase "droserasin" in the digestive fluid of Drosera sp. like dionain and dionaeasin in Dionaea muscipula. This resemblance is reasonable since Dionaea and Drosera sp. are closely located in the phylogenetic tree. It remains to be clarified what kind of reducing agent is present in the digestive fluids of these carnivorous plants to activate the cysteine endopeptidases.

\section{References}

Athauda, S.B.P., Inoue, H., Iwamatsu, A., and Takahashi, K. 1998. Acid proteinase from Nepenthes distillatoria (Badura). Adv. Exp. Med. Biol. 436: 453-458.

Athauda, S.B.P., Inoue, H., Iwamatsu, A., and Takahashi, K. 2002. Purification and enzymatic characterization of an aspartic proteinase (Nepenthesin) from the insectivorous plant Nepenthes distillatoria. Proc. $4^{\text {th }}$ Interntl. Carnivor. Plant Conf. Tokyo, 117-124.

Athauda, S.B.P., Matsumoto, K., Rajapakshe, S., Kuribayashi, M., Kojima, M., Kubomura-Yoshida, N., Iwamatsu, A., Shibata, C., Inoue, H., and Takahashi, K. 2004. Enzymic and structural characterization of nepenthesin, a unique member of a novel subfamily of aspartic proteinases. Biochem. J. 380: 295-306.

Takahashi, K., Athauda, S.B.P., Matsumoto, K., Rajapakshe, S., Kuribayashi, M., Kaga, T., Muramatsu, M., Niwa, H., Shimaya, K., Kubota, K., Nishii, W., Kojima, M., Inoue, H., Kubomura, N., Iwamatsu, A., and Shibata, C. 2003. Unique characteristics of carnivorous plant aspartic proteinases with special reference to nepenthesin. Program and Abstracts, Interntl. Conf. Asp. Proteases and Inhibitors, Kyoto, 20.

Takahashi, K., Athauda, S.B.P., Matsumoto, K., Rajapakshe, S., Kuribayashi, M., Kojima, M., Kubomura-Yoshida, N., Iwamatsu, A., Shibata, C., and Inoue, H. 2005. Nepenthesin, a unique member of a novel subfamily of aspartic proteinases: enzymatic and structural characteristics. Curr. Protein Pept. Sci. 6: 513-525.

Takahashi, K., Matsumoto, K., Nishii, W., Murakami, M., Kubota, K., Shibata, C., and Athauda, S.B.P. 2009. Comparative studies on the acid proteinase activities in the digestive fluids of $\mathrm{Ne}$ penthes, Cephalotus, Dionaea, and Drosera. Carniv. P1. Newslett. 38: 75-82.

Takahashi, K., Suzuki, T., Nishii, W., Kubota, K., Shibata, C., Isobe, T., and Dohmae, N. 2011. A cysteine endopeptidase ("dionain") is involved in the digestive fluid of Dionaea muscipula (Venus's fly-trap). Biosci. Biotechnol. Biochem. 75: 346-348.

\section{CPN REVIEWERS}

Lubomír Adamec

John Brittnacher

Marcel van den Broek
Andreas Fleischmann

Siegfried Hartmeyer

Barry Rice
Fernando Rivadavia

Jan Schlauer

Bob Ziemer 